\title{
Medical prescription: conditioned reflex or conscious reflection?
}

\author{
Mucio Moreno, Oscar Arrieta, Rubén Burgos, Carlos Campillo, Miguel Á. Celis, Manuel de la Llata, \\ Judith Domínguez, José Halabe, Sergio Islas, Luis Jasso, Alberto Lifshitz, Ricardo Plancarte, \\ Alejandro Reyes-Sánchez, Guillermo Ruiz-Argüelles, Antonio Soda, Emma Verástegui and Julio Sotelo* \\ Academia Nacional de Medicina de México, Comité de Ética y Transparencia en la Relación-Médico-Industria, Mexico City, Mexico
}

\begin{abstract}
Writing a prescription or indicating a treatment is usually the last part of medical consultation. This crucial process can be undermined by multiple factors such as limited prescriptive ability, overwork, and lack of reflection or time. Insufficient information about the patient or the treatment affects the prescriptive process and leads to errors that can be serious for patient health. The National Academy of Medicine, in line with the World Health Organization, emphasizes the relevance of making the prescriptive process a reflective exercise.
\end{abstract}

KEY WORDS: Medical prescription. Medicines. Medical diagnosis. Medical treatment. Pharmacotherapy.

\section{La receta médica: ¿reflejo condicionado o reflexión consciente?}

\section{Resumen}

Extender una receta o indicar un tratamiento suele ser la última parte de la consulta médica. Este proceso crucial puede desvirtuarse debido a múltiples factores como capacidad prescriptiva limitada, exceso de trabajo y falta de reflexión o tiempo. La información insuficiente acerca del paciente o del tratamiento afecta el proceso prescriptivo y propicia errores que pueden ser graves para la salud del enfermo. La Academia Nacional de Medicina, en consonancia con la Organización Mundial de la Salud, hace énfasis en hacer del proceso prescriptivo un ejercicio de reflexión.

PALABRAS CLAVE: Prescripción médica. Receta médica. Medicamentos. Diagnóstico médico. Tratamiento médico. Farmacoterapia.

Writing the prescription for the patient is usually the last part of medical consultation. This act brings together the effort of diagnostic exercise, crystallizes the acuity of professional judgment and gives consistency to medical science. It is highly relevant for medical prescription always to include the four mnemonic "R's": it must be reasonable, reasoned, rationed and rationalized. It is equally important to insist on doctor's handwriting in the prescription, which should always be clear and understandable.

Patients are increasingly becoming actively involved in what the doctor prescribes them, are better informed about their ailment, treatment options, risks and complications; with all this, their demands on the doctor have grown, with the expectation of participating in the prescriptive choice.
Correspondence:

*Julio Sotelo

E-mail: jsotelo@ unam.mx
Gac Med Mex. 2020;156:603-605

Contents available at PubMed

www.gacetamedicademexico.com

0016-3813/@ 2020 Academia Nacional de Medicina de México, A.C.. Published by Permanyer. This is an open access article under the CC BY-NC-ND license (http://creativecommons.org/licenses/by-nc-nd/4.0/). 
Poor prescription habits are a source of ineffective and unsafe treatments that can exacerbate or prolong the disease, cause stress and harm to the patient and increase costs, as the World Health Organization (WHO) observes. ${ }^{1}$ When analyzing the prescriptive capacity of newly graduated young doctors who were evaluated during undergraduate training and six months after graduation, half of them were observed to select an inappropriate or questionable drug, one third did not correctly write down the prescription and two thirds could not academically support the prescribed drug. Some physicians indicated that their prescribing habits would improve later upon completion of undergraduate training, yet research showed that prescriptive skills did not have much advances after graduation despite the acquisition of experience in general.

During clinical training, insufficient emphasis is placed on how to choose a drug and on the information that should accompany the prescriptive act. Most medical schools primarily focus on theoretical pharmacological knowledge and invest little effort in prescriptive abilities acquisition.

The WHO observes that poor prescribing habits contribute for the prescriber to be vulnerable to influences that can promote irrational prescribing, such as patient pressure, inappropriate practices from colleagues and information provided by pharmaceutical industry sales representatives. Prescribing should be part of a logical deductive process, based on global and objective information. It should not be a reflex action or a response to commercial pressure.

With the experience of a study in medical students focused on the prescription process, the WHO proposed a "guide to good prescribing", which was reviewed by experts in pharmacotherapy teaching. Regardless of professional experience level, it is advisable to review if in our medical practice we comply with the reasoned therapeutic process recommended by the WHO in six steps, namely:

1. Define the patient's problem.

2. Specify the therapeutic objective, what is it that is wanted to achieve with the treatment?

3. Verify if the treatment is adequate, effective and safe.

4. Start treatment.

5. Give information, instructions and warnings.

6. Monitor (and stop?) the treatment.

In clinical practice, when a doctor cares for 30 to 40 patients daily in an institution, it is difficult for him/her to complete a reasoned therapeutic process in each case. Considering that it will not always be possible to follow the WHO recommendations for a "good prescription" step by step, in the following paragraphs, the Committee for Ethics and Transparency in the Physician-Industry Relationship (CETREMI - Comité de Ética y Transparencia en la Relación Médico-Industria) $)^{2}$ suggests the following considerations regarding these six proposals:

- Careful analysis, structured history taking and complete physical examination will allow the medical condition and associated anxiety, which may require additional help, as well as difficulties in treatment-adherence, to be clearly defined. Medical intervention success will depend on prescription proper selection. In many cases, the prescription of drugs is not necessary. Patient pressure to receive some specific drug or treatment can mask an additional problem.

- A clear definition of the therapeutic objective is essential for an adequate prescription and will avoid the use of unnecessary drugs, such as prescribing antibiotics or anti-parasitic drugs in case of fever, or an ointment with corticosteroids and antibiotics for not differentiating between mycosis and eczema, etc. It is always a good idea to discuss the therapeutic objective with the patient, as it turns him/her into an informed "partner" and improves treatment adherence. The art of medical prescription consists of differentiating each patient as a particular case from the rest.

- The main characteristic to indicate a treatment or drug is its efficacy; however, it should also be safe and convenient. Owing to various mechanisms, many of them genetic in nature, a patient can be different from average, with differences in drug pharmacodynamics and pharmacokinetics that modify the therapeutic margin and window. Clinically this might generate "resistance" or "hypersensitivity" to the drug.

- The dosing schedule should be convenient, i.e., the more complex the dosing schedule, the less convenient. A drug reaches its ideal blood concentration when there is a balance between its absorption, distribution, metabolism and excretion. Any modification of these factors influences its potential efficacy, and although plasma level of a drug can be measured, doing it is expensive and hard to interpret; it is easier to look for clinical signs of response and side effects. Treatment duration and drug doses should also be 
individualized. For example, many cancer outpatients suffer from pain, and the physician is afraid to prescribe morphine for long periods, mistaking tolerance for addiction.

- Patient adherence to prolonged treatments is problematic. Often, the patient discontinues a drug when symptoms improve or unwanted effects appear. For patient and doctor convenience, prescription "automatic renewal" is common; however, this is a reason for excessive or unnecessary prescribing, particularly in patients with chronic conditions. It is important to emphasize that the doctor is responsible for ensuring that the prescription is clear and legible, precisely indicating the data that identify the patient (name, address and age), the date, generic name of the drug, total quantity and exact dose, frequency and route of administration, treatment period, instructions and warnings, responsible physician signature and contact information.

- Statistics indicate that half the patients do not take the medication correctly. In some studies, less than $60 \%$ of patients understand how to take the medication. Each patient requires understanding doctor's instructions and solving doubts or concerns. Having too many patients should not be an excuse to avoid properly instructing them regarding their medical prescription. ${ }^{3}$

Monitoring of treatment allows the doctor to determine if the expected result has been obtained. To achieve this, it will be necessary to maintain adequate communication with the patient.
The doctor has the obligation to know about pharmacological advances. Commercial information that is commonly handled by pharmaceutical companies in promotional campaigns can be biased and not academically supported.

\section{Conflicts of interest}

The authors declare that they have no conflicts of interest.

\section{Funding}

The authors did not receive any sponsoring to carry out this article.

\section{Ethical disclosures}

Protection of human and animal subjects. The authors declare that no experiments were performed on humans or animals for this research.

Confidentiality of data. The authors declare that no patient data appear in this article.

Right to privacy and informed consent. The authors declare that no patient data appear in this article.

\section{References}

1. Tichelaar J, Richir MC, Garner S, Hogerzeil H, de Vries PGM. WHO guide to good prescribing is 25 years old: quo vadis? Eur $\mathrm{J}$ Clin Pharmacol. 2020;76:507-513.

2. Academia Nacional de Medicina. Comité de Ética y Transparencia de los Médicos con la Industria Farmacéutica (CETREMI). Gac Med Mex. 2015;151:293

3. Celis MA, Halabe J, Arrieta A, Burgos R, Campillo C, de la Llata M, et al. El consentimiento informado: recomendaciones para su documentación. Gac Med Mex. 2019;154:716-718. 